\title{
O ofício da escrita: uma sondagem do fazer literário por meio de cartas de Caio Fernando Abreu
}

\author{
The writing work: a study of the literary writing process through Caio Fernando Abreu's letters
}

Doutorando do Programa de Pós-Graduação em Estudos Literários da Faculdade de Ciências e Letras da UNESP, Campus Araraquara. Docento do Centro Universiáa Barão de Mauá e do Centro Universitário

andre alselmi@yahoo.com.br
RESUMO: Os gêneros íntimos - o diário, a autobiografia e a carta - vêm conquistando cada vez mais espaço entre os leitores, por, dentre outros motivos, promoverem uma ilusão de verdade. Em decorrência disso, esses textos têm ganhado bastante espaço em editoras, tornando-se cada vez mais visíveis nas livrarias. 0 mesmo ocorre com as correspondências de personalidades literárias, que têm despertado grande interesse da crítica em compreender os fundamentos dessa forma de expressão e de sua relação com a criação literária. Inegavelmente, é preciso reconhecer que as cartas de grandes escritores frequentemente transcendem o mero relato cotidiano, revelando uma carga poética e informacional digna de ser analisada com vistas a compreender o processo de criação literária. Nesses casos, a correspondência de grandes escritores é relevante não apenas pelo seu valor autobiográfico, histórico ou cultural, mas também por ser uma forma de expressão autônoma e múltipla capaz de acolher a reflexão sobre a literatura e o processo de criação. Partindo do pressuposto de que a experiência pessoal e a experiência literária, nas epístolas de Caio Fernando Abreu, apresentam-se concomitantemente, este artigo extrai das cartas do autor uma poética a partir das reflexões metalinguísticas sobre a natureza da criação literária e do ofício do escritor. Assim, por meio da correspondência de Caio Fernando Abreu, este artigo traça uma visão do escritor gaúcho sobre a função da literatura, a imagem do escritor e o processo de escrita. Com isso, pretende-se demonstrar que as cartas constituem um rico material para a compreensão do universo literário do autor.

PALAVRAS-CHAVE: Caio Fernando Abreu; cartas; Criação literária; Ofício do escritor.

ABSTRACT: The intimate genres - the diary, autobiography and the letter - are gaining more and more space among readers, because, among other things, they promote a real illusion. As a result, these texts have gained enough space in publishing, becoming more and more visible in bookstores. The same applies to the letters of literary authors who have aroused great interest in the literary criticism in understanding the fundamentals of this form of expression and its relationship to literary creation. Undeniably, one must recognize that the letters of great writers often transcend the mere daily report, revealing a great poetic and informational content to be analyzed in order to understand the process of literary creation. In such cases, the correspondence of great writers is not only because his autobiographical historical or cultural values, but also because it is an autonomous form of expression that is capable of express multiple reflection on the literature and the writing process. Assuming that personal experience and literary experience appear concomitantly in Caio Fernando Abreu's letters, this article analyzes the author's poetic letters from metalinguistic reflections on the nature of literary writing and the writer's work. Thus, by studying Caio Fernando Abreu's correspondence, this article draws the view of the function of literature that of this gaúcho writer had, the writer's image and the writing process. With this study we intend to demonstrate that the letters are a rich material that can be used to understand the author's literary universe.

KEYwoRDS: Caio Fernando Abreu; Letters; Literary writing; Writer's work. 


\section{Introdução}

$\mathrm{N}$

as últimas décadas, os gêneros íntimos (as confissões, as memórias, a autobiografia, o diário e a carta) vêm despertando a atenção dos leitores e da crítica literária. Tal fato é intensificado pela atual tendência ao culto da individualidade e ao prazer de acompanhar a vida cotidiana alheia, que hoje toma uma parte significativa da mídia e da realidade. Diante disso, as correspondências de personalidades literárias - por muito tempo negligenciadas pelos estudos literários e pelos leitores - ganham destaque e ocupam um espaço sem precedentes. Assim, as cartas têm suas publicações multiplicadas, o que tem despertado grande interesse da crítica em compreender os fundamentos dessa forma de expressão e de sua relação com a criação literária.

Sem dúvida, é preciso reconhecer que as missivas de grandes escritores não raro transcendem o mero relato autobiográfico, trazendo, frequentemente, uma carga poética e informacional passível de ser analisada com vistas a entender o processo de criação literária. Nesses casos, a carta não interessa apenas como um testemunho biográfico ou documento histórico ou cultural, mas também como uma forma de expressão autônoma e múltipla capaz de acolher a reflexão sobre a literatura e o processo de criação.

Embora a escrita de cartas tenha sido frequente em autores como Machado de Assis, Mário de Andrade, Manuel Bandeira, Pedro Nava e Clarice Lispector - entre outros -, escritores significativos das décadas de 70 e 80 também encontraram nas epístolas um instrumento de expressão, algumas “[...] vezes com a função de laboratório para a literatura, outras simplesmente para informar ou manter laços de amizade ou profissionais." (PIOVESAN, 2010, p. 1-2). Dentre eles, pode-se destacar Caio Fernando Abreu que, segundo sua biógrafa, Jeanne Callegari,
[...] era compulsivo em relação a escrever cartas: adorava conhecer pessoas novas, porque assim tinha mais gente com quem trocar correspondência. Caio escrevia três, quatro cartas por dia, às vezes, e eram cartas longas, de várias páginas, em que ele se expunha muito. (CALLEGARI, 2008, p. 113-114)

Considerado um dos nomes mais expressivos da geração pós-64, a literatura de Caio Fernando Abreu reflete o questionamento das diversas formas de autoritarismo, dos mecanismos de poder, denunciando a insatisfação da juventude diante de uma realidade asfixiante caracterizada por repressão, censura, consumismo e desigualdades sociais. Por outro lado, a literatura do autor também é marcada pela vertente intimista, que se manifesta na prosa de introspecção, na qual ganha importância a interioridade e a psicologia individual dessa geração.

Nos 25 anos de produção literária, o escritor gaúcho publicou dois romances, sete livros de contos, uma história infanto-juvenil, uma antologia de contos e uma peça de teatro. Além disso, integrou coletâneas com outros autores e teve algumas de suas obras traduzidas para diversas línguas. Como jornalista, colunista, editor e colaborador de vários órgãos de imprensa (jornais como Zero Hora, Folha da Manhã e o Estado de São Paulo; revistas como Manchete, IstoÉ, Veja, entre outras), publicou crônicas e suplementos literários. Ademais, escreveu roteiros de cinema e de programas de televisão. Hoje, há edições póstumas de textos, muitos deles inéditos - como as crônicas publicadas em jornais. Além disso, o acervo literário do autor, no instituto de Letras da UFRGS, ainda conserva muito material inédito.

$\mathrm{O}$ interesse pelo estudo das correspondências de Caio Fernando Abreu se deu a partir da publicação de Cartas, obra organizada por Italo Moriconi em 2002. No prefácio, Luciano Alabarse afirma que

Cada carta é joia burilada pela mão do exigente ourives. Tanto para os que conviveram com Caio como aqueles que não o puderam conhecer, este livrodocumento é importante porque nele estão presentes, intactas, a palavra implacável e a real estatura do grande escritor. (MORICONI, 2002, p. 9-10) 
As palavras de Alabarse sinalizam a importância que assume a correspondência do escritor gaúcho para a compreensão do processo de criação literária. Assim, para Caio Fernando Abreu escrever cartas não é uma atividade secundária marcada pela simples necessidade de comunicar-se. Frequentemente, como em muitos autores modernos, trata-se de conciliar expressão e reflexão sobre o processo criativo.

A coletânea Cartas (2002) - reúne a produção mais significativa do escritor no gênero. A multiplicidade dos destinatários (familiares, amigos, escritores, jornalistas, atores, entre outros) propicia o emprego de tons que vão do informal ao lírico, revelando as diversas facetas do autor: "O Caio erudito, o Caio pop, o Caio filosófico, o Caio abobrinha, o Caio deprimido." (CALLEGARI, 2008, p. 11) e, poderíamos acrescentar, o Caio poeta e artesão da palavra. Essa diversidade encontra na carta, devido à maleabilidade e flexibilidade do gênero, uma das formas de expressão mais eficientes.

Partindo do pressuposto de que a experiência pessoal e a experiência literária, nas epístolas de Caio Fernando Abreu, apresentam-se concomitantemente, este artigo pretende extrair das cartas do autor uma poética a partir das reflexões metalinguísticas sobre a natureza da criação literária e do ofício do escritor. Assim, por meio da correspondência do autor, buscarse-á traçar uma visão deste sobre a função da literatura, a imagem do escritor e o processo de escrita. Com isso, pretende-se demonstrar que as cartas constituem também um rico material para a compreensão do universo literário do autor.

No primeiro capítulo de seu livro Poesia-experiência (1976), Mário Faustino discute as principais questões que envolvem o fazer literário: "Para que Poesia?"; “O poeta e seu mundo"; “Que é poesia?”. A partir de uma análise que transcende as barreiras nacionais, o poeta brasileiro demonstra como esses tópicos são trabalhados em grandes nomes da literatura, como Edgar Allan Poe, Théophile Gautier, Walt Whitman, Charles Baudelaire,
Emily Dickinson, dentre outros. Embora as reflexões de Faustino refiram-se sobretudo à poesia, suas ideias podem ser facilmente aplicadas à literatura, em sua concepção mais ampla. A fim de demostrar a consonância entre o pensamento do escritor gaúcho e as grandes linhas da poesia universal, este artigo revelará os pontos de contato entre as reflexões literárias presentes nas cartas de Caio Fernando Abreu e as correntes da alta literatura mundial apontadas por Faustino. Com esse mesmo intuito, serão apresentados alguns pontos de contato entre as ideias do escritor gaúcho e as reflexões tecidas por Theodor Adorno em sua "Palestra sobre lírica e sociedade".

\section{Pelas entrelinhas de Caio Fernando breu: o ofício da escrita}

Muito se tem discutido sobre a função da literatura e diversas têm sido as funcionalidades atribuídas ao texto literário. Distanciando-se de uma postura autotélica, Caio Fernando Abreu, assim como Mário Faustino, também acredita que, dentre as suas várias funções, a literatura constitui um meio "[...] de comover os homens; [...] meio de ensiná-los.” (FAUSTINO, 1976, p. 28). Isso pode ser notado, por exemplo, em carta a Thereza Falcão $(15 / 05 / 1980)^{1}$, em que o autor escreve sobre As frangas, obra infantojuvenil:

E acho que Frangas tem, também, seu lado mais sério. Que não é necessariamente chato ou pedante. Umas mensagenzinhas ecológicas, ideológicas, para fazer a cabeça das crianças - por que não? Desde que sem didatismo idiota, claro (ABREU, 2002, p. 170)

Nesse trecho, percebe-se que, para o autor, a ideologia da obra não deve estar presente de maneira explícita, constituindo um "didatismo idiota".

1 As indicações entre parênteses referem-se às datas das cartas citadas. 
Assim como Adorno, o escritor gaúcho acredita que os "Conceitos sociais não devem ser trazidos de fora às composições líricas, mas sim devem surgir da rigorosa intuição delas mesmas.” (ADORNO, 2003, p. 67). O fundo ideológico deve, portanto, constituir o pano de fundo da obra, pois não se pode esquecer que literatura é, mais do que arte das ideias, arte das palavras. Portanto, trata-se, segundo Faustino, de uma conjugação de ética (pensamento) e estética (linguagem), relação que compõe "[...] uma base mesma de toda filosofia da arte" (FAUSTINO, 1976, p. 57).

Mário Faustino reconhece como lícita essa postura do escritor que põe sua literatura a serviço de sua verdade política ou social e reconhece que "Em todas as épocas [...] estiveram os artistas, uns mais outros menos, a serviço de ideologias, serviço ora mais determinado, ora menos consciente." (FAUSTINO, 1976, p. 36). E parece claro que Caio Fernando Abreu tinha plena consciência disso. Em carta a Luiz Fernando Emediato (06/10/1976), o escritor confessa:

Eu não sei se um dia as coisas realmente mudam, mas procuro, em tudo que escrevo (que é meu jeito de agir sobre o mundo), colaborar de alguma maneira para que essa mudança venha. (ABREU, 2002, p. 481)

O trecho acima alinha-se ao pensamento de Faustino, para o qual “[...] poesia não é apenas música e imagem: é também pensamento. Tal pensamento é resultado de uma reflexão sobre o universo [...]." (FAUSTINO, 1976, p. 50). Em carta a Hilda Hilst (29/12/1970), ao comentar sobre a leitura da obra Fluxo-Floema, o escritor reconhece: "Tenho certeza que através desse livro outras pessoas vão aprender contigo tudo o que eu aprendi, e que é imenso. (ABREU, 2002, p. 411)". Portanto, fica claro que a literatura, por encerrar um pensamento, uma reflexão, constitui um instrumento de aprendizado. Entretanto, pode-se dizer que, ao invés de alegrar, a literatura de Caio constitui uma espécie de aprendizado pela dor. Em carta à sua mãe (15/09/1983), ao comentar sobre sua obra Triângulo das águas, o escritor revela:

Acho que é meu melhor livro, mas é também o mais terrível - porque é preciso falar claramente sobre certas coisas, é preciso alertar as pessoas para a vida errada que levam, a alimentação errada, as emoções erradas, os relacionamentos errados. Não quero ser dono da verdade, mas aprend algumas coisas nesses anos - pode parecer ambicioso, mas de repente gostaria de ajudar a transformar este mundo numa coisa melhor. (ABREU, 2002, p. 62-63)

De fato, o leitor da obra de Caio irá se deparar com uma literatura reflexiva e intimista, marcada por um sujeito fragmentado inserido em um mundo torto. Não é gauche apenas o indivíduo, mas também o próprio meio em que ele se encontra inserido. Conforme ressalta Faustino, essa vontade de transformar o universo parece estar relacionada "[...] à posição órfica, demiúrgica, cosmorrevolucionária, própria dos poetas que sabem colocar-se não à margem, mas ao centro móvel da corrente dos tempos." (FAUSTINO, 1976, p.57). Trata-se de um sujeito em busca de uma dupla transformação: a sua e a do universo. É o que ocorre, por exemplo, no conto - considerado um dos mais autobiográficos - "Pequeno monstro", de Os dragões não conhecem o paraíso: a transformação do adolescente constitui uma mudança de todo universo ao seu redor.

Além de ensinamento, para Caio Fernando Abreu a literatura também se apresenta como uma forma de experimentação e de conhecimento do mundo e, consequentemente, constitui uma maneira de autoconhecimento e de organização do próprio ser. Em outras palavras, por meio da literatura, como destaca Mário Faustino, "[...] o poeta fala também a si próprio, organizando-se através de sua poesia." (FAUSTINO, 1976, p. 31). Em carta a Sérgio Keuchgerian (27/01/1987), Caio afirma: 
E penso tantas outras coisas, mas o real não se modifica. E o real, parece meio grosso dito assim, mas no fundo é isso mesmo - o real é: R. Não quer trepar comigo de jeito nenhum.

Como dói.

Mas tenho anotado histórias, anotado sem parar. Está vindo algo por aí, se avolumando. Talvez seja o único jeito, não? Minhas ficções não me rejeitam. Talvez seja sina, essa de escrever, e então ter as respostas da vida real na vida recriada, nunca na própria vida real - como as pessoas que não criam costumam ter. E deve estar certo assim, deve haver uma ordem e um sentido nisso. (ABREU, 2002, p. 149-150)

$\mathrm{O}$ fragmento demonstra que a ficcionalidade apresenta-se para o autor como uma forma de experimentação da realidade e, consequentemente, de aprendizado. Mário Faustino reconhece que, de fato, o poeta é um homem que, mais do que observar o universo, tem a necessidade de experimentá-lo, obrigando-o a reagir às palavras com que o ataca, lamenta ou celebra. Isso demonstra que os homens "[...] historicamente, têm aproveitado tanto do conhecimento poético, quanto de qualquer outro método de conhecer." (FAUSTINO, 1976, p. 32).

Essa fusão entre vida e literatura, fazendo com que esta se torne uma forma de experiência - aliás, tão legítima quanto a experiência vivida - pode ser ainda percebida em carta enviada a Jacqueline Cantore (18/04/1985), em que o escritor comenta a escrita do romance Onde andará Dulce Veiga?: "Dulce teria agora por volta de 50/55 anos. Procurei os maxilares de Dulce toda a tarde na cidade. Mas o problema é: em que direção Dulce terá se transformado?" (ABREU, 2002, p.130). Pode-se notar que, imerso no processo de escrita, a literatura confunde-se com a própria vida do autor.

Então, pode-se afirmar que ao escritor uma vida não basta. Como já observava Rimbaud, "À chaque être, plusieurs autres vies me semblaient dues" (1980, p. 101). Como também já demonstrou explicitamente Fernando Pessoa, com a criação de seus heterônimos, para o poeta, a literatura e a ficcionalidade apresentam-se como extensões da experiência real imediata e, no caso de Caio, além da possibilidade de novas formas de experimentação, a escrita apresenta-se como uma alternativa face à realidade asfixiante. É o que reconhece o escritor em carta a João Silvério Trevisan (20/11/1977): “Ô, João, ando meio fatigado de procuras inúteis e sedes afetivas insaciáveis, e a minha saída (uma saída gostosa) tem sido essa: a literatura." (ABREU, 2002, p.496). Ou, ainda, em post scriptum em carta enviada a José Márcio Penido (21/06/1979): "PS2 - Seja como for, torno a descobrir que a literatura, essa deusa-cadela, é a coisa que mais tenho amado na vida." (ABREU, 2002, p. 515).

Em carta a Jacqueline Cantore (01/11/1983), ao comentar o suicídio de Ana Cristina César, com quem teve muita proximidade, o escritor escreve: "Com que direito, Deus, com que direito ela fez isso? Logo ela, que tinha uma arma para sobreviver - a literatura -, coisa que pouca gente tem?" (ABREU, 2002, p. 73). Mais uma vez, ao condenar a postura de Ana C., o escritor deixa explícita a saída encontrada por ele: o refúgio na ficcionalidade. De acordo com Mário Faustino, nesse sentido a poesia - e por extensão a literatura - ocupa papel central na vida de um escritor "E é por isso que a vida de um poeta perde completamente seu sentido quando, porventura, se vê ele definitivamente impedido de fazer poesia." (FAUSTINO, 1976, p. 31).

Além dessas funções, a literatura de Caio também pode ter um papel de representação. Faustino ressalta que "[...] a poesia é como toda arte: um documento vivo, expressivo, do estado de espírito de um certo povo, em dada região, numa época determinada." (1976, p. 33). De fato, a crítica reconhece que a literatura caiofernandiana constitui - ao lado de produções de autores como Ana Cristina César e Hilda Hilst - um dos melhores retratos da geração pós-64. Em carta a José Márcio Penido (22/12/1979), o escritor comenta: 
Mas o melhor que li nesses dias não foi ficção. Foi um pequeno artigo de Nirlando Beirão na última IstoÉ (do dia 19 de dezembro, please, leia), chamado 'O recomeço do sonho'. Li várias vezes. Na primeira, chorei de pura emoção - porque ele reabilita todas as vivências que eu tive nesta década. Claro que ele fala de uma geração inteira, mas daí saquei, meu Deus, como sou típico, como sou estereótipo da minha geração. Termina com uma alegria total: reinstaurando o sonho. É lindo demais. É atrevido demais. É novo, sadio. Deu uma luz na minha cabeça, sabe quando a coisa te ilumina? (ABREU, 2002, p. 521)

Obviamente, muitos indivíduos poderiam ser considerados típicos representantes de sua geração. Entretanto, assim como nem todo pintor é capaz de captar, por meio das diferentes tintas, pinceladas e nuances o Zeitgeist de um povo, nem todo homem é capaz de, por meio da linguagem, oferecer um retrato tão verdadeiro de sua geração. Cabe ao bom escritor ser o artesão da palavra. Mas, afinal, quem é o poeta?

Mário Faustino enxerga o poeta como um

[...] homem dotado de certa capacidade de percepção e expressão, ambas verbais (assim como tanto a percepção como a expressão específicas de um músico são mais uma questão de sons) que o tornam especialmente apto para harmonizar - intrinsicamente e um em relação ao outro - os dois universos: um tangível - natureza e sociedade - e outro intangível: o das palavras em todos os seus aspectos de som, idéia e imagem. 0 poeta seria, portanto, aquele homem que, capaz de receber os fenômenos naturais e sociais de modo especialmente sintéticos, e também capaz de exprimir em palavras organicamente relacionadas, essa visão totalizadora de um mundo e de uma época. (FAUSTINO, 1976, p. 43-44)

Portanto, fica evidente que o poeta possui uma dupla habilidade: de percepção (tangível) e de expressão (intangível). Além disso, possui também a capacidade de promover a fusão entre estes dois elementos: imagem e palavra. Do mesmo modo, em carta endereçada a José Márcio Penido (22/12/1979), o escritor gaúcho reconhece que o escritor apresenta-se como um ser com habilidades especiais, diferenciado dos demais homens:
Eu conheci razoavelmente bem Clarice Lispector. Ela era infelicíssima, Zézim. A primeira vez que conversamos eu chorei depois a noite inteira, porque ela inteirinha me doía, porque parecia se doer também, de tanta compreensão sagrada de tudo. Te falo nela porque Clarice, pra mim, é o que mais conheço de GRANDIOSO, literariamente falando. E morreu sozinha, sacaneada, desamada, incompreendida, com fama de 'meio doida'. Porque se entregou completamente ao seu trabalho de criar. Mergulhou na sua própria trip e foi inventando caminhos, na maior solidão. Como Joyce. Como Kafka, louco e só lá em Praga. Como Van Gogh. Como Artaud. Ou Rimbaud. (ABREU, 2002, p. 518)

No trecho, a expressão "compreensão sagrada de tudo" parece remeter à capacidade singular, que nos aponta Faustino, “[...] de perceber imediatamente, em conjunto, em conflitos, que se completam, o todo e suas partes, a um tempo dependente e independentemente." (FAUSTINO, 1976, p. 49). Na mesma carta, Caio revela ao amigo: “Quando terminei Morangos mofados, escrevi embaixo, sem querer, "criação é coisa sagrada”. É mais ou menos o que diz o Chico no fim daquela matéria. É misterioso, sagrado, maravilhoso." (ABREU, 2002, p. 522).

Também em carta enviada a Sérgio Keuchgerian (10/08/1985), o escritor relata:

Dormi umas três horas e acordei ouvindo Quereres, de Caetano. Repeti, várias vezes, cada vez mais alto. Ah, bruta flor, bruta flor do querer. Discutia tanto com Ana Cristina Cesar, antes que ela acolhesse a morte (acertadamente? Me pergunto até hoje, nunca sei responder): nossa necessidade fresca \& neurótica de elaborar sofrimentos e rejeições e amarguras e pequenos melodramas cotidianos para depois sentar Atormentado e Solitário para escrever Belos Textos Literários.

O escritor é uma das criaturas mais neuróticas que existem: ele não sabe viver ao vivo, ele vive através de reflexos, espelhos, imagens, palavras. 0 não-real, o não-palpável. Você me dizia 'que diferença entre você e um livro seu'. Eu não sou o que escrevo ou sim, mas de muitos jeitos. Alguns estranhos. (ABREU, 2002 , p. $140-141)$ 
Mais uma vez, o fragmento evidencia que o poeta é dotado não só de uma capacidade de visão diferenciada, mas também de um modo de vida particular. Em algumas de suas cartas, Caio deixa clara a sua ideia de que o escritor é um ser escolhido. É o que pode ser notado, por exemplo, em carta enviada a Charles Kiefer (14/04/1983):

Sabe que tenho MEDO de escrever? Evito sempre que posso. Dá uma exaustão, depois. Uma exaustão agradável, mas a cabeça fica excitada demais, é qualquer coisa muito próxima da loucura. Mas nos últimos tempos não tenho conseguido evitar. Vai saindo. É meio assustador. (ABREU, 2002, p. 42)

Portanto, pode-se perceber que o pensamento de Caio Fernando Abreu alinha-se ao de Adorno, para quem "[...] somente a pouquíssimos homens [...] foi dado apreender o universal no mergulho em si mesmos, ou foi permitido que se desenvolvessem como sujeitos autônomos, capazes de se expressar livremente." (ADORNO, 2003, p. 75). O poeta apresenta-se, nesse sentido, como alguém tomado por uma espécie de imposição que - no caso de Caio - oscila entre vocação e karma, pois "Mesmo que não se esteja escrevendo realmente, a gente está sempre escrevendo por dentro." (ABREU, 2002, p. 42). 0 próprio escritor reconhece esse fato em carta endereçada a Maria Lídia Magliani (16/06/1992):

Enfim, estou intoxicado de mediocridade literária. E - oba! - tenho pretextos ótimos para não escrever meus próprios textos. Tenho fugido lindo da labuta. Vou jogando frases, recortes, pedaços dentro de uma pasta. Branca, naturalmente. E há um stadenervos crescente, aquela sensação de não estar cumprindo o karma como devia. (ABREU, 2002, p. 234)

Para Caio, o karma reside sobretudo no fato de o escritor ser geralmente alguém incompreendido, o que o conduz constantemente ao isolamento. Além de observar isso na vida de Clarice Lispector, o próprio escritor vivencia esse apartheid e o revela em carta aos pais (12/08/1987):
Estou me transformando aos poucos num ser humano meio viciado em solidão. E que só sabe escrever. Não sei mais falar, abraçar, dar beijos, dizer coisas aparentemente simples, como 'eu gosto de você'. Gosto de mim. Acho que é o destino dos escritores. E tenho pensado que, mais do que qualquer outra coisa, sou um escritor. Uma pessoa que escreve sobre a vida - como quem olha de uma janela - mas não consegue vivê-la.

Amo vocês como quem escreve para uma ficção: sem conseguir dizer nem mostrar isso. 0 que sobra é o áspero do gesto, a secura da palavra. Por trás disso, há muito amor. Amor louco - todas as pessoas são loucas, inclusive nós [...] Mas amor de verdade. Perdoem o silêncio, o sono, a rispidez, a solidão. Está ficando tarde, e eu tenho medo de ter desaprendido o jeito. É muito difícil ficar adulto. (ABREU, 2002, p. 153)

A carta revela o dilema do escritor: tomado por uma capacidade de percepção e de expressão singulares, acaba por se divergir da massa. Portanto, a literatura, ao mesmo tempo em que se apresenta a ele como um refúgio, também impõe-se, paradoxalmente, como um karma, visto que só por meio dela consegue viver de maneira plena e intensa.

É preciso considerar, entretanto, que a vocação do poeta não o livra da obrigação de preparar-se para exercer seu ofício. Faustino acredita que “[...] a partir do momento em que um homem decide que tem, potencialmente, aquela capacidade de perceber e de expressar a que nos referimos, será seu dever alimentar, aperfeiçoar e exercer, ao máximo, essa dupla aptidão." (FAUSTINO, 1976, p. 44). Caio parece ter tido consciência dessa obrigação do escritor, pois, em carta a José Márcio Penido (22/12/1979), observa:

E ler, ler é alimento de quem escreve. Várias vezes você me disse que não conseguia mais ler. Que não gostava mais de ler. Se não gostar de ler, como vai gostar de escrever? Ou escreva então para destruir o texto, mas alimente-se. Fartamente. (ABREU, 2002, p. 519)

Pode-se perceber que, para o escritor, a leitura apresenta-se como fonte de conhecimento, de preparação (sensorial e intelectual) e de formação do 
próprio artista. As cartas de Caio também revelam seus gostos como leitor e suas maiores influências: "Lispector, Virgínia Woolf, Proust, Drummond, Pessoa, por aí” (ABREU, 2002, p. 485).

Outro aspecto relevante a ser abordado é a responsabilidade social do escritor. Segundo Faustino, "[...] o poeta critica o universo e a sociedade e, por isso mesmo, que os ama, procura agir sobre eles, experimentando-os para melhorá-los. (1976, p. 45). Portanto, cabe ao escritor perturbar o leitor, retirando-o de sua zona de conforto. É justamente essa a posição de Caio Fernando Abreu, evidente em carta endereçada a Hilda Hilst (27/03/1973):

Achei uma epígrafe ótima, duma letra de Gilberto Gil para uma música chamada Zooilógico, assim: "Eu sou o menino que abriu a porta das feras / no dia quem que todas as famílias visitavam o zôo". Não é uma glória? E o livro é exatamente isso: a violência e a loucura soltas para grilar os bem-pensantes. No momento, acredito muito no grilo como arte, não sei se você entende. (ABREU, 2002, p. 437-438)

Além de deixar clara a postura do escritor em relação à responsabilidade ética e moral do escritor, o fragmento citado reforça a ideia de literatura como instrumento de transformação social, assunto já discutido neste artigo.

Por fim, em relação ao escritor, cabe dizer que ele é um ser que, partindo das experiências pessoais, é capaz de transcendê-las, atingindo o coletivo, de maneira que este se reconheça em seus escritos. Em sua "Palestra sobre lírica e sociedade", Adorno faz algumas considerações sobre a poesia que podem ser perfeitamente aplicadas à literatura intimista de Caio:

[...] o teor [Gehalt] de um poema não é a mera expressão de emoções e experiências pessoais. Pelo contrário, estas só se tornam artísticas quando, justamente em virtude da especificação que adquirem ao ganhar forma estética, conquistam sua participação no universal. Não que aquilo que o poema lírico exprime tenha de ser imediatamente aquilo que todos vivenciam. Sua universalidade não é uma volonté de tous, não é da mera comunicação daquilo que os outros simplesmente não são capazes de comunicar. Ao contrário, o mergulho no individuado eleva o poema lírico ao universal por tornar manifesto algo de não distorcido, de não captado, de ainda não subsumido, [... A composição lírica tem esperança de extrair, da mais irrestrita individuação, o universal. [...] Essa universalidade do teor lírico, contudo, é essencialmente social. (ADORNO, 2003, p. 66-67).

Ainda segundo Adorno, “[...] em cada poema lírico devem ser encontrados, no médium do espírito subjetivo que se volta sobre si mesmo, os sedimentos da relação histórica do sujeito com a objetividade, do indivíduo com a sociedade." (2003, p. 72). Entretanto, para o teórico, essa relação entre o subjetivo e o coletivo deve estar cristalizada de maneira implícita no texto. Cabe à linguagem fazer essa mediação entre o particular e o coletivo e, ao poeta, utilizar a linguagem de modo a construir implicitamente essa relação. Caio parece reconhecer esse papel universal da literatura, ao escrever para José Márcio Penido (02/11/1990), comentando sobre o romance Onde andará Dulce Veiga?:

Mas vamos lá, tudo por Dulce Veiga. Divulgue ele(a), sinto que é como se fosse meu primeiro livro, no sentido de que me desembaracei do umbigo e chegue mais perto da ficção, do Brasil, do humano alheio, não apenas meu. (ABREU, 2002, p. 193)

Pelo fragmento, percebe-se como o escritor é dotado de uma visão totalizadora da realidade. Por meio da linguagem, paradoxalmente a subjetividade transforma-se em objetividade e é capaz de tocar o coração do universal.

Por fim, feitas as considerações sobre a função da literatura e a imagem do poeta, cabe demonstrar como as cartas de Caio revelam a concepção do processo de escrita do autor. A disputa entre inspiração e trabalho artístico também remonta à antiguidade e já teve as mais diferentes teses. Hoje, é comum reconhecer-se que o texto literário é fruto de uma conjugação de 
ambos os elementos. Essa também parece ser a postura do escritor gaúcho. Ao reconhecermos que o poeta é dotado de uma capacidade de percepção e de expressão, estamos legitimando, respectivamente, o papel da inspiração e do trabalho artístico na criação literária.

A respeito da inspiração, por meio de suas cartas, Caio revela que esta aparece como lampejos, momentos instantâneos em que frases lhe vêm à cabeça. É o que revela em carta a Luciano Alabarse (24/08/1984): “Têm me vindo frases na cabeça. Vou anotando. Ontem, uma, tão insistente, assim: "Fiquei ali parado, procurando alguma coisa que não estava nem esteve ou estaria jamais ali." (ABREU, 2002, p. 95). Muitas vezes, tais ideias lhe aparecem involuntariamente, chocando o próprio escritor: "Mas tenho medo de sentar para escrever minhas próprias coisas, Luciano - há demônios às vezes incontroláveis que vêm à tona." (ABREU, 2002, p. 111).

Em carta a José Márcio Penido (22/12/1979), ao discorrer sobre o processo de escrita, Caio aconselha seu amigo: que não procure o seu texto:

[...] ele vem até você, quando você e ele estiverem prontos. Cada um tem seus processos, você precisa entender os seus. De repente, isso que parece ser uma dificuldade enorme pode estar sendo simplesmente o processo de gestação do sub ou do inconsciente. (ABREU, 2002, p. 519)

Isso revela a importância que Caio dá à inspiração. Na mesma correspondência, ao comentar sobre a obra Morangos mofados, revela:

O fim se meteu no texto e não admitiu que eu interferisse. Tão estranho. Às vezes penso que, quando escrevo, sou apenas um canal transmissor, digamos assim, entre duas coisas totalmente alheias a mim, não sei se você entende. Um canal transmissor com um certo poder, ou capacidade, seletivo, sei lá. Hoje pela manhã não fui à praia e dei o conto por concluído, já acho que na quarta versão. Mas vou deixá-lo dormir pelo menos um mês, aí releio - porque sempre posso estar enganado, e os meus olhos de agora serem incapazes de verem certas coisas. (ABREU, 2002, p. 520)
No fragmento acima, ao colocar-se como um "canal transmissor", o escritor explicita que a criação literária depende primeiramente da inspiração. Em seguida, ao revelar que irá deixar o texto "dormir pelo menos um mês", revela que o processo de criação também é fruto de um esforço consciente, de um trabalho de lapidação da escrita. Esse esforço, alias, é reconhecido em carta a Luciano Alabarse (02/08/1990): “Então fica assim: Onde andará Dulce Veiga? foi o livro que mais me doeu. Veja só: em nenhum momento ele fluiu. Foi escrito gota-a-gota, palavra por palavra." (ABREU, 2002, p. 186). O processo de escrita é ainda metaforizado em duas cartas a José Márcio Penido. No fragmento a seguir (02/11/1990), mais uma vez, Caio comenta o trabalho de composição de Onde andará Dulce Veiga?:

Foram umas duas mil páginas para tirar pouco mais de 200. Cada vez mais literatura para mim é aquele tipo de escultura em pedra bruta. Dentro da pedra há uma forma, que você precisa localizar e tirar a golpes de formão. No braço, no muque. Quando cheguei à frase final - que já existia desde que escrevi a primeira - tive uma crise de choro de quase uma hora. Meio exaustão, meio orgasmo, meio não sei o quê. Só repetia, na terceira pessoa, Caio F. Caio F. Você conseguiu. (ABREU, 2002, p. 190)

Por fim, ainda em suas reflexões sobre o processo de criação, em outra carta a Penido (22/12/1979), Caio comenta as dificuldades de escrita do amigo:

Pra mim, e isso pode ser muito pessoal, escrever é enfiar um dedo na garganta. Depois, claro, você peneira essa gosma, amolda-a, transforma. Pode sair até uma flor. Mas o momento decisivo é o dedo na garganta. E eu acho - e posso estar enganado - que é isso que você não tá conseguindo fazer. Como é que é? Vai ficar com essa náusea seca a vida toda? E não fique esperando que alguém faça isso por você. Ocê sabe, na hora do porre brabo, não há nenhum dedo alheio disposto a entrar na garganta da gente. (ABREU, 2002, p. 590) 
Por meio de uma linguagem metaforizada, carregada de voltagem poética, Caio revela sua visão sobre a concepção literária: pedra bruta ou gosma, não há produção sem o árduo trabalho do escritor. Aqui, chegamos a uma das questões centrais do texto literário: o uso da linguagem.

Embora parte da produção de Caio seja intelectualmente acessível ao público - sobretudo as crônicas publicadas no jornal $O$ Estado de São Paulo -, parte da produção do escritor é de difícil compreensão para um público pouco familiarizado com a linguagem literária. É o caso, por exemplo de Triângulo das águas, considerada uma das obras mais herméticas do autor. Esse hermetismo da linguagem - marcada por ausência de pontuações, neologismos e rupturas sintáticas -, além de representar a própria fragmentação do indivíduo, apresenta-se também como uma forma de resistência. Isso pode ser percebido em carta enviada a Lucienne Samôr (27/11/1995), em que o escritor aconselha: “[...] NÃO FACILITE SEU TEXTO, não escreva pensando em vender porque aí não vai prestar. (ABREU, 2002, p. 340).

Segundo Adorno, em uma sociedade dominada pela mercadoria e pela massificação,

[...] o poema enuncia o sonho de um mundo em que essa situação seria diferente. A idiossincrasia do espírito lírico contra a prepotência das coisas é uma forma de reação à coisificação do mundo, à dominação das mercadorias sobre os homens, que se propagou desde o início da Era Moderna e que, desde a Revolução Industrial, desdobrou-se em força dominante na vida. (ADORNO, 2003, p. 69]

Não só a linguagem, mas a própria literatura constitui esse espaço de resistência, conforme demonstra Caio em carta ao seu amigo José Márcio Penido (22/12/1979):
Você quer escrever. Certo, mas você quer escrever? Ou todo mundo te cobra e você acha que tem que escrever? Sei que não é simplório assim, e tem mil coisas outras envolvidas nisso. Mas de repente você pode estar confuso porque fica todo mundo te cobrando, como é que é, e a sua obra? Cadê o romance, quedê a novela, quedê a peça teatral? DANEM-SE, demônios. Zézim, você só tem que escrever se isso vier de dentro pra fora, caso contrário não vai prestar eu tenho certeza, você poderá enganar a alguns, mas não enganaria a si e, portanto, não preencheria esse oco. Não tem demônio nenhum se interpondo entre você e a máquina. 0 que tem é uma questão de honestidade básica. Essa perguntinha: você quer mesmo escrever? Isolando as cobranças, você continua querendo? Então vai, remexe fundo, como diz um poeta gaúcho, Gabriel de Britto Velho, 'apaga o cigarro no peito / diz pra ti o que não gostas de ouvir / diz tudo'. Isso é escrever. Tira sangue com as unhas. E não importa a forma, não importa a 'função social', nem nada, não importa que, a princípio, seja apenas uma espécie de auto-exorcismo. Mas tem que sangrar a-bun-dan-te-men-te. (ABREU, 2002, p. 517-518)

O fragmento evidencia que, para o autor, a literatura genuína não deve se render às demandas mercadológicas. Ao afirmar que a "função social" não importa, o escritor deixa claro que a criação literária não deve se subordinar às expectativas sociais. Entretanto, esse tipo de atitude, obviamente, acarreta consequências nem sempre positivas:

Você não está com medo dessa entrega? Porque dói, dói, dói. É de uma solidão assustadora. A única recompensa é aquilo que Laing diz que é a única coisa que pode nos salvar da loucura, do suicídio, da auto-anulação: um sentimento de glória interior. Essa expressão é fundamental na minha vida.

É esse tipo de criador que você quer ser? Então entregue-se e pague o preço do pato. Que, freqüentemente, é muito caro. Ou você quer fazer uma coisa bemfeitinha pra ser lançada com salgadinhos e uísque suspeito numa tarde amena na Cultura, com todo mundo conhecido fazendo a maior festa? Eu acho que não. Eu conheci / conheço muita gente assim. E não dou um tostão por eles todos. A você eu amo. Raramente me engano. (ABREU, 2002, p. 518)

A não submissão do escritor às vontades editoriais tem suas vantagens a salvação "da loucura, do suicídio, da auto-anulação" -, mas também tem seu 
preço, que também é assumido pelo escritor, banido das relações sociais: “De repente eu me vi adulto e de mãos vazias, sem sequer um eletrodoméstico para satisfazer essas pessoas que nos exigem realizações o tempo todo." (ABREU, 2002, p. 420).

\section{Conclusão}

A partir da análise das missivas, primeiramente demonstramos como o autor esboça algumas funções para a literatura, enxergando nela: uma forma de ensinamento; uma maneira de experimentar o mundo, compreendendose e organizando-se por meio de seus escritos; uma alternativa face à realidade limitante, refugiando-se na ficcionalidade; uma forma de registrar a sociedade.

Em seguida, traçamos, por meio das cartas, a imagem do escritor para Caio: um homem dotado de capacidade de percepção e expressão verbais; um ser escolhido, marcado por uma espécie de imposição que oscila entre vocação e karma; um homem com responsabilidade ética e moral; alguém que possui uma visão totalizadora da realidade, capaz de expressar o coletivo por meio do particular.

Por fim, demonstramos como as epístolas revelam a concepção do escritor sobre a criação literária: um constante equilíbrio entre inspiração e trabalho artístico. Comentamos, ainda, como literatura e a linguagem literária apresentam-se como forma de resistência ao mundo das mercadorias.

A partir das considerações tecidas neste artigo, pode-se concluir que, para Caio Fernando Abreu, mais do que um mero relato de experiências pessoais, as cartas constituem um espaço de reflexão sobre a literatura. As correspondências do autor revelam um escritor consciente das questões que a crítica levantava a respeito da poesia e, além disso, demonstram o quanto seu pensamento encontra-se em consonância com as ideias de grandes autores do século XX sobre a criação artística. Portanto, para além de seu valor histórico, deve-se reconhecer às cartas de Caio Fernando Abreu o seu valor enquanto suporte para discussão e reflexão sobre o fazer literário, revelando o pensamento artístico do escritor.

\section{Referências}

ABREU, Caio Fernando. Cartas. Org. Italo Moriconi. Rio de Janeiro: Aeroplano, 2002.

ADORNO, Theodor W. Palestra sobre lírica e sociedade. In: __. Notas de literatura I. Trad. Jorge de Almeida. São Paulo: Duas Cidades, Editora 34, 2003. p. 65-89.

CALLEGARI, Jeanne. Caio Fernando Abreu: o inventário de um escritor irremediável. São Paulo: Seoman, 2008.

FAUSTINO, Mário. Poesia-experiência. São Paulo: Perspectiva, 1976.

MORICONI, Italo (Org.). Cartas - Caio Fernando Abreu. Rio de Janeiro: Aeroplano, 2002.

PIOVESAN, Greyce Kelly. As mulheres de Letras no universo epistolar de Pedro Nava In: Fazendo Gênero 9: Diásporas, Diversidades, Descolamentos. 2010. Disponível em: <http://www.fazendogenero.ufsc.br/9/resources/anais/1277936346_ARQUIVO_ trabalhoFAZENDOGENERO.pdf. Acesso em 10/08/13>.

RIMBAUD; Latréamont; CORBIÈRE; Cros. Oeuvres poétiques complètes. Paris: Édition Robert Laffont, 1980.

Recebido em 20 de dezembro de 2015. Aceito em 05 de março de 2015 . 